liberated society finds it is as easy to talk about urinary incontinence as about sexual behaviour.

\section{LINDA CARDOZO}

Consultant Obstetrician and Gynaecologist,

King's College Hospital,

London SE5 9RS

1 Van de Velde TH. Ideal marriage. New York: Covici-Friede, 1930.

2 Hardenbergh EW. The psychology of feminine sex experience. International fournal of Sexology 1949;2:224-8

3 Ellis H. Psychology of sex. 2nd ed. New York: Emerson Books, 1954

4 Masters WH, Johnson VE. Human sexual response. London: Churchill, 1966.

5 Dalton JR, Bergquist EJ. Urinary tract infections. London: Croom Helm, 1987:2.

6 Robertson J. Genitourinary problems in women. Springfield, Illinois: Thomas, 1978:106-14.

Gillespie L. The diaphragm: an accomplice in recurrent urinary tract infections. Urolog $1984 ; 254: 240-5$.

8 Vessey MP, Metcalfe MA, McPherson K, Yeates D. Urinary tract infection in relation to diaphragm use and obesity. Int $\mathcal{F}$ Epidemiol 1987;16:1-4.

9 Kilmartin A. Understanding cystitis. 2nd ed. London: Pan Books, 1975.

9 Kilmartin A. Understanding cystitis. 2nd ed. London: Pan Books, 1975.

$10 \mathrm{Cardozo} \mathrm{LD}$. Urinary frequency and urgency. $\mathrm{Br}$ Med $\mathcal{f} 1986 ; 2$

11 Sutherst JR. Sexual dysfunction and urinary incontinence. Brf Obstet Gynaecol 1979;86:387-8. Clinical gynecological urology. Toronto: C V Mosby, 1984:398-405.

13 Hilton P. Urinary incontinence during sexual intercourse: a common, but rarely volunteere symptom. Brf Obstet Gynaecol (in press).

14 Cardozo LD. Sexually induced urinary incontinence. British fournal of Sexual Medicine 1987;14:154.

15 Grafenberg E. The role of urethra in female orgasm. International fournal of Sexology 1950;3 $145-8$.

16 Ladas AK, Whipple B, Perry JD. The $G$ spot and other recent discoveries about human sexuality. London: Corgi Books, 1983.

\section{Prescribing psychotropic drugs in general practice}

It is a paradox that most psychotropic drugs are prescribed in general practice yet most of the studies showing their value have been carried out in patients seen by psychiatrists. Generalising from one population to the other is legitimate only if the specialist sample is representative of the general population, but this is rarely established. Antidepressants and benzodiazepine hypnotics and tranquillisers are the most commonly prescribed psychotropic drugs, accounting for about one in six of all prescriptions. ${ }^{1}$ It is difficult to know whether these drugs are being inappropriately prescribed; published evidence merely tells us that antidepressants are effective in moderate and severe depressive illness ${ }^{2}$ and that benzodiazepines are extremely effective in promoting sleep and relieving anxiety in the short term. ${ }^{34}$ The clinical trials that have been published give little indication of which patients should receive the drugs and for how long.

Excessive growth in prescriptions for benzodiazepines in the 1970s led to concern over their use. ${ }^{5}$ The concern was reinforced by evidence that they were being prescribed for excessively long periods. ${ }^{6}$ Subsequent studies have shown that about two fifths of regular users of benzodiazepines develop pharmacological dependence and have withdrawal symptoms when the dosage of their drugs is reduced or treatment is stopped..$^{7-9}$ Potential consumers now distrust all psychotropic drugs, and prescribing is more cautious.

Some indications of whether psychotropic drugs are being used correctly in general practice have come from four recent papers, two published in this issue (p 601 and p 603). Paykel and others have shown unequivocally in a placebo controlled trial that amitriptyline is effective in the depressed patients seen in general practice and that such patients can tolerate doses normally recommended for clinical efficacy (up to 175 mg of amitriptyline daily). ${ }^{10}$ They also show, however, that patients with mild depression (scores of 12 or less on the Hamilton rating scale ${ }^{11}$ ) are not helped by this dose of amitriptyline. There was a significant improvement with amitriptyline compared with placebo after only two weeks of treatment, a shorter period than that reported from psychiatric practice. ${ }^{2}$ The magnitude of drug placebo differences was also greater than in most psychiatric studies, which is not surprising. Patients referred to psychiatrists by general practitioners are more resistant cases and are also more likely to have personality disorders ${ }^{12-14}$; these differences might account for the lesser response to antidepressants seen in psychotropic patients.

Tricyclic antidepressants thus do improve depressive illness seen in general practice. They are not placebos with unpleasant side effects. There has been doubt over their efficacy in general practice patients ever since Porter's influential study published 18 years ago, ${ }^{15}$ although the reasons for the disparity between his results and those of Paykel and others are not clear. What is less certain is the value of the common practice of prescribing antidepressants such as amitriptyline over a long period in low dosage. Mant and others ${ }^{16}$ confirmed the findings ${ }^{617}$ that long term prescribing of antidepressants is common and that the mean dose given (under $50 \mathrm{mg}$ daily) is less than that recommended. Although studies in psychiatric patients suggests that $75 \mathrm{mg}$ daily is inadequate, there may still be benefit in milder depression; and many general practitioners would deny strongly that $50 \mathrm{mg}$ daily is merely a placebo dose.

The prescribing dose of benzodiazepines is better defined. We have long known that long term prescription of these compounds is wrong ${ }^{18}$ and that dependence becomes more likely as the treatment period gets longer. ${ }^{1920}$ This is reinforced by Mant and others showing that when benzodiazepines had been prescribed for six months in regular dosage the prescription was likely to become semipermanent. Because even the short term prescription of benzodiazepines may lead to withdrawal problems some practitioners recommend avoiding them altogether. ${ }^{21}{ }^{22}$ Short term reassurance and counselling are equally effective and do not carry the same risk of adverse effects. ${ }^{23}$

The elderly are, however, regarded differently. Not only are they the group most likely to be prescribed benzodiazepines long term, ${ }^{124}$ but, as Rodrigo and others have shown, they have a high incidence of physical illness associated with their psychiatric disturbance (p 603). Although the conclusions of Morgan and others that many of these long term users are likely to be dependent is almost certainly correct ( $p$ 601), there are more apologists for long term treatment in the elderly than in the young. Benzodiazepines are muscle relaxants and anticonvulsants as well as sedatives and, despite their risks, have fewer side effects than other sedative drugs. The feeling has also developed that dependence is not so important in the elderly as in the young. These assumptions may be wrong, but it would be interesting to know whether counselling and psychotherapy would be as effective as benzodiazepines in the elderly.

Despite some reservations, the prescribing of psychotropic drugs in general practice appears to be improving and is much more carefully monitored than it was ten years ago. A large deficiency in our knowledge is the best way of managing those who take psychotropic drugs long term, usually in combination. It is unconstructive to criticise the doctor for regular prescribing if there are no feasible alternatives.

P TYRER

Consultant Psychiatrist,

Mapperley Hospital,

Nottingham NG3 6AA 
1 Skegg DCG, Doll R, Perry J. Use of medicines in general practice. Br Med f 1977;i: 1561-3. 2 Morris JB, Beck AT. The efficacy of anti-depressant drugs. Arch Gen Psychiatry 1974;30:667-74. 3 Lader MH, Bond AJ, James DC. Clinical comparison of anxiolytic drug therapy. Psychol Med 1974;4:381-7.

4 Briggs RS, Castelden CM, Kraft CA. Improved hypnotic treatment using chlormethiazole and temazepam. BrMed f 1980;280:601-4.

5 Trethowan WH. Pills for personal problems. Br Med f 1975;iii:749-51.

6 Tyrer P. Drug treatment of psychiatric patients in general practice. Br Med f 1978;ii:1008-10.

7 Tyrer PJ. Benzodiazepine dependence and propranolol. Pharmaceutical fournal 1980;225:158-60.

7 Tyrer PJ. Benzodiazepine dependence and propranolol. Pharmaceutical fournal 1980;225:158-60. 1981;283:643-5.

9 Tyrer P, Owen R, Dawling S. Gradual withdrawal of Diazepam after long-term therapy. Lancet 1983;i:1402-6.

10 Paykel ES, Hollyman JA, Freeling P, Sedgwick P. Predictors of therapeutic benefit from amitriptyline in mild depression: a general practice placebo-controlled trial. $\mathcal{F}$ Affective Disord 1988;14:83-95.

11 Hamilton M. A rating scale for depression. F Neurol Neurosurg Psychiatry 1960;23:56-62.

12 Tyrer P, Casey P, Gall J. Relationship between neurosis and personality disorder. Br f Psychiatry $1983 ; 142: 404-8$.

13 Tyrer P, Seivewright H. Studies of outcome. In: Tyrer P, ed. Personality disorder; diagnosis, management, and course. John Wright: Bristol (in press).

14 Casey P, Dillon S, Tyrer PJ. The diagnostic status of patients with conspicuous psychiatric morbidity in primary care. Psychol Med 1984;14:673-81.

15 Porter AMN. Depressive illness in general practice: A demographic study and a controlled trial of imipramine. BrMed f 1970;i:773-8.

16 Mant A, Duncan-Jones P, Saltman D, et al. Development of long term use of psychotropic drugs by general practice patients. BrMed f 1988;296:251-4.

17 Johnson DAW. The treatment of depression in general practice. Br Med f 1973;ii:18-20.

18 Committee on review of medicines. Systematic review of benzodiazepine. Br Med $\mathrm{f}$ 1980;280:910-2

19 Lader M. Dependence on benzodiazepines. F Clin Psychiatry 1983;44:121-7.

20 Kales A, Bixler EO, Tan T-L, et al. Chronic hypnotic-drug use: ineffectiveness, drug-withdrawal, insomnia, and dependence. $\mathscr{F} A M A$ 1974;227:513-7.

21 Fontaine R, Chouinard G, Annable L. Rebound anxiety in anxious patients after abrupt withdrawal of benzodiazepine treatment. Am $\mathcal{F}$ Psychiatry 1984;141:848-52.

22 Murphy SM, Owen R, Tyrer P. Withdrawal symptoms after six weeks treatment with diazepam. urphy SM, Owen R,
Lancet 1984;ii: 1389 .

23 Catalan J, Gath D, Edmonds G, Ennis J, Bond A, Martin P. The effects of non prescribing of anxiolytics in general practice: controlled evaluation of psychiatric and social outcome. Brf Psychiatry 1984;144:593-610.

24 Balter MB, Manheimer DI, Mellinger GD, Uhlenhuth EH. A cross-national comparison of antianxiety/sedative drug use. Curr Med Res Opin 1984;8 (Suppl 4):5-20.

\section{The pathogenesis of acute pancreatitis}

We still do not know the underlying mechanisms of acute pancreatitis. Nevertheless, it is believed to result from autodigestion from the activation of precursor enzymes within the gland, and certain causal factors, such as alcoholism and gall stones, may play an important part.

Other proposed factors, however, are based on flimsy evidence derived from a few case reports and do not stand up to scrutiny. For example, a handful of case reports suggest that some drugs (such as contraceptives, thiazide diuretics, and corticosteroids) may cause acute pancreatitis. Nevertheless, many prescriptions are issued every year for these drugs but in only a few instances are they associated with acute pancreatitis-which suggests coincidence rather than causality. Only one controlled study of drug induced pancreatitis has implicated thiazide diuretics, ${ }^{1}$ and an association with azathioprine emerged from the National Cooperative Crohn's Disease Study. ${ }^{2}$ Similarly, the few reported cases of acute pancreatitis associated with hypercalcaemia and hyperparathyroidism pale into insignificance compared with the large numbers of patients with these conditions who never have any features of the disease. Judgment must even be suspended on the often quoted hyperlipidaemia as a causal factor given that we now know how often some instances result from alcohol abuse.

Another proposal in the pathogenesis was obstruction of a common biliary-pancreatic channel by gall stones. Nevertheless, such obstruction is rare 3 : only $4 \%$ of 2653 patients with acute pancreatitis had stones in the common bile duct ${ }^{4}$ and a common anatomical channel is rarely present in those with acute pancreatitis. ${ }^{5}$ Moreover, studies in animals have shown that obstruction of the pancreatic duct causes atrophy of the exocrine gland without pancreatitis, and some evidence even suggests that obstruction will protect the gland from pancreatitis in both animals ${ }^{6}$ and man. ${ }^{7}$

Undoubtedly, however, duodenopancreatic reflux may be a potent causal factor for acute pancreatitis. It was cogently argued almost 20 years ago that reflux of the duodenal contents through a papilla (inflamed perhaps by alcohol, the passage of a stone, endoscopic cannulation or a recent surgical operation) might be the common factor underlying many of the aetiological associations. ${ }^{8}$ Such duodenal contents contain enterokinase and other activated enzymes capable of activating the proenzymes in the pancreas if they come into contact with the proenzymes. This mechanism might account for the development of oedematous (interstitial) pancreatitis, though again the latter is usually self limiting and rarely progresses to severe (haemorrhagic/necrotic) pancreatitis.

Keynes has suggested on clinical and histological grounds that oedematous pancreatitis is not merely the mild end of a range of severity. ${ }^{9} \mathrm{He}$ further argues that, in contrast to oedematous disease, haemorrhagic pancreatitis does not result from autodigestion by activated pancreatic proenzymes but from the presence of cytotoxin producing bacteria. In few patients does oedematous pancreatitis progress to haemorrhagic disease, and hence possibly an external factor other than autodigestion may determine progression. ${ }^{10}$ Primary infection may be one such factor, and certainly some of the damaging enzymes in pancreatitis seem to be bacterial. ${ }^{11}$ Bacterial toxins may precipitate pancreatitis ${ }^{12}$ and since the contents of the upper small intestine normally contain about 1000 organisms per ml, the refluxing duodenal contents would be far from sterile. Hence Keynes's suggestions should be studied further.

Given that some of the normal mediators of inflammation cannot activate pancreatic proenzymes in vitro, ${ }^{13}$ then a hypothesis of a directly acting cytotoxic factor which causes necrosis in acute pancreatitis is attractive. Nevertheless, how does duodenopancreatic reflux cause pancreatitis in the tail of a gland without similarly damaging the head and body, as sometimes occurs? Furthermore severe pancreatitis is known to be induced in germ free animals. ${ }^{14}$

To understand this important disease we have to establish both the role and the frequency of duodenopancreatic reflux in acute pancreatitis as well as the frequency of primary infection and its relation to the severity of the disease. But at present duodenopancreatic reflux seems to be a major factor in causing pancreatitis, while any role for primary infection is speculative.

R E BARRY

Consultant Senior Lecturer in Medicine,

Bristol Royal Infirmary,

Bristol BS2 8HW

1 Bourke JB, Mclllmurray MB, Mead GM, Langman MJS. Drug associated primary acute pancreatitis. Lancet 1978;i: 706-8.

2 Singleton JW, Law DH, Kelley ML, Mekhiian HS, Sturdevant RAL. National Cooperative Crohn's Disease Study: Adverse reactions to study drugs. Gastroenterology 1979;77:870-82.

3 Shader AE, Paxton JR. Fatal pancreatitis. Am f Surg 1966;111:369-73.

4 White TT. Results of 89 operations for pancreatitis: a personal experience. Surgery 1965;58: 1061-74.

5 McCutcheon AD. Aetiology factors in pancreatitis. Lancet 1962;i:710-2.

6 McCutcheon AD, Race D. Experimental pancreatitis: a possible etiology of postoperative pancreatitis. Ann Surg 1962;155:523-31.

7 Sinclair ISR. Acute pancreatitis: primary and postoperative. f R Coll Surg Edinb 1959;5:57-76. $8 \mathrm{McCutcheon}$ AD. A fresh approach to the pathogenesis of pancreatitis. Gut 1968;9:296-310.

9 Keynes WM. The mythology of acute pancreatitis. Infections in Surgery 1987;6:354-68.

10 Kelly TR. Pathological anatomy and pathogenesis of acute pancreatitis. World f Surg 1981;5: 309-10.

11 Keynes WM. A non pancreatic source of the proteolytic enzyme amidase and bacteriology in experimental pancreatitis. Ann Surg 1980;191:187-99.

12 Thal AP, Molestina JP. Studies on pancreatitis III. Fulminating haemorrhagic pancreatic necrosis produced by means of staphylococcal toxin. Arch Pathol Lab Med 1955;60:212-20.

13 Guyan PM, Butler J, Braganza JM. Oxygen free radicals do not activate the zymogens of human pancreatic proteases. Gut 1987;10:A1394.

14 Nance FC, Cairn JL. Haemorrhagic pancreatitis in germ free dogs. Surgical Forum 1967; 18:365-7. 